\title{
HUBUNGAN PENGETAHUAN DAN SIKAP PERAWAT GIGI DENGAN PENERAPAN KOMUNIKASI TERAPEUTIK DI BP GIGI PUSKESMAS KABUPATEN AGAM
}

\author{
${\text { Zulfikri }{ }^{*}}^{*}$
}

\begin{abstract}
ABSTRAK
Standar kompetensi perawat gigi, salah satu diantaranya adalah mampu melakukan komunikasi terapeutik di tempat pelayanan kesehatan gigi dengan kliennya, antara lain menjelaskan kegiatan yang akan dilakukan, memberi kesempatan klien untuk bertanya, merencanakan tindak lanjut serta melakukan kontrak untuk perawatan gigi selanjutnya. Penelitian ini bertujuan untuk mengetahui hubungan pengetahuan dan sikap perawat gigi dalam menerapkan komunikasi terapeutik di BP Gigi Puskesmas Kabupaten Agam.

Jenis penelitian ini adalah explanatory research, dengan metode penelitian survei, dengan pendekatan cross sectional. Sampel penelitian adalah semua perawat gigi yang bekerja di Puskesmas Kabupaten Agam sebanyak 41 orang, data diambil dengan cara wawancara langsung menggunakan kuesioner terstruktur.

Hasil penelitian menunjukkan bahwa penerapan komunikasi terapeutik di BP gigi Puskesmas Kabupaten Agam masih kurang (63,4\%). Variabel yang yang berhubungan secara signifikan terhadap variabel terikat adalah variabel sikap ( $p$. Value 0,008), sedangkan pengetahuan perawat gigi tidak ditemukan adanya hubungan yang signifikan dengan penerapan komunikasi terapeutik (p. Value 0,743).
\end{abstract}

Kata kunci : komunikasi terapeutik, kompetensi perawat gigi, BP gigi Puskesmas

\begin{abstract}
One of the competence standards of dental nurses is able to conduct a therapeutic communication at the dental health service with their clients; among the communicated matters are describing the activities that will be conducted, giving the clients the chances to ask, planning the follow-ups, and conducting contracts of the next dental care. This research has the objective of analyzing the factors influencing dental nurses in implementing the therapeutic communication at the Dental Service Division of the Public Health Center of Agam Regency.

This research was an explanatory research, with survey as the research method, using the crosssectional approach. The research samples were all dental nurses working at the Public Health Center of Agam Regency, as many as 41 people. Data were collected by direct interviews using a structured questionnaire.

The research results showed that the implementation of therapeutic communication at the Dental Service Division of the Public Health Center of Agam Regency was still inadequate (63.4\%). Variables that were significantly related to the dependent variable is the attitude variables ( $p$. Value 0.008), whereas knowledge of dental nurses did not reveal any significant association with the application of therapeutic communication (p. Value 0.743).
\end{abstract}

Key words : therapeutic communication, competence of dental nurses, dental service division of the public health center

${ }^{*}$ Dosen Jurusan Keperawatan Gigi Poltekkes Kemenkes Padang

$凶$ : fikrijkg@gmail.com 


\section{PENDAHULUAN}

Seiring dengan kemajuan ilmu pengetahuan dan teknologi serta makin meningkatnya kebutuhan masyarakat akan pentingnya pelayanan kesehatan yang diselenggarakan di rumah sakit maupun puskesmas, dirasakan adanya kehati-hatian bagi pasien yang memerlukan pengobatan dan perawatan. Kehati-hatian tersebut ditandai dengan harapan pasien terhadap kesembuhan penyakitnya dan keinginan pelayanan kesehatan yang baik oleh petugas kesehatan. Pelayanan yang baik akan dirasakan oleh pasien sebagai rasa percaya, rasa aman dan puas. Percaya akan kemampuan petugas kesehatan, aman dari segala akibat yang mungkin terjadi sewaktu dirawat dan puas akan hasil yang didapat yaitu kesembuhan pasien (Kusmawan, 2016).

Steiber menjelaskan, bahwa keluhan yang sering disampaikan oleh klien yang tidak puas akan pelayanan keperawatan adalah tentang lamanya menunggu perawat setelah klien masuk ruang perawatan, lamanya perawat menjawab panggilan klien, sikap perawat yang tidak bersahabat, kurang perhatian, kurangnya perawat memberikan pendidikan kesehatan tentang perawatan di rumah dan perawat tidak menjelaskan tentang prosedur tindakan/ pengobatan serta proses penyakit. Hal ini menunjukkan bahwa faktor penyebab ketidakpuasan klien adalah kurangnya interaksi atau tidak adanya komunikasi terapeutik antara perawat dengan klien (Sukendro, 2008).

Sesuai dengan standar kompetensi, peran atau tugas perawat gigi, salah satu diantaranya adalah kemampuan melakukan komunikasi terapeutik dengan pasien (Depkes, 2007). Menurut Machfoedz, komunikasi terapeutik merupakan komunikasi yang dilakukan oleh perawat atau tenaga kesehatan lain yang direncanakan dan berfokus pada kesembuhan pasien (Machfoedz, 2009). Dalam melakukan hubungan komunikasi terapeutik dengan pasien, perawat mempunyai 4 tahap yang harus diselesaikan, yaitu tahap prainteraksi, tahap orientasi, tahap kerja dan tahap terminasi (Sukendro, 2008).

Penelitian ini bertujuan untuk mengidentifikasi dan menganalisis hubungan pengetahuan dan sikap perawat gigi dalam menerapkan komunikasi terapeutik di BP gigi Puskesmas Kabupaten Agam.

\section{METODE PENELITIAN}

Jenis penelitian ini adalah eksplanatory reseach, dengan pendekatan cross sectional. Teknik pengambilan data dengan wawancara menggunakan kuesioner yang telah di siapkan. Tempat penelitian adalah di semua Puskesmas Kabupaten Agam. Variabel dependen dalam penelitian ini adalah penerapan komunikasi terapeutik oleh perawat gigi, sedangkan variabel independent adalah pengetahuan dan sikap perawat gigi. Populasi dalam penelitian ini adalah semua perawat gigi yang bekerja di Puskesmas Kabupaten Agam yang berjumlah 41 orang. Teknik pengambilan sampel dalam penelitian ini adalah total sampling yaitu semua populasi dijadikan sampel atau penelitian populasi.

\section{HASIL DAN PEMBAHASAN}

Hasil penelitian tentang penerapan komunikasi terapeutik bagi perawat gigi di puskesmas Kabupaten Agam dapat dilihat pada tabel di bawah ini :

Tabel 1. Penerapan komunikasi terapeutik di BP Gigi Puskesmas Kabupaten Agam

\begin{tabular}{clcc}
\hline \multirow{2}{*}{ No } & $\begin{array}{c}\text { Penerapan Komunikasi } \\
\text { terapeutik }\end{array}$ & \multicolumn{2}{c}{ Total } \\
& \multicolumn{1}{c}{ f } & $\%$ \\
\hline 1 & Kurang & 26 & 63,4 \\
2 & Baik & 15 & 36,6 \\
\hline \multicolumn{2}{c}{ Total } & 41 & 100 \\
\hline
\end{tabular}

Dari tabel 1 dapat dilihat bahwa sebagian besar perawat gigi dalam menerapkan komunikasi terapeutik berada pada kategori kurang 63,4\%, dan yang kategori baik sebesar $36,6 \%$. 
Berdasarkan hasil penelitian sebagian besar masih masuk dalam kategori kurang menjalankan $(63,4 \%)$ komunikasi terapeutik. Beberapa hal yang masih kurang dan perlu mendapat perhatian dalam penerapan komunikasi terapeutik adalah perawat gigi belum sepenuhnya menerapkan komunikasi non verbal pada pasien secara optimal, didapatkan sebanyak $75,7 \%$ perawat gigi tidak membungkukkan atau memiringkan badan mereka saat melakukan percakapan dengan klien, serta 51,3\% mereka kurang memberikan tanggapan terhadap perilaku yang ditampilkan klien. Dikhawatirkan apabila proses komunikasi tidak dilakukan secara maksimal, maka harapan untuk mendapatkan respon dari lawan komunikasi (komunikan) tidak bisa tercapai dengan baik, karena dalam berkomunikasi kita sangat berharap adanya reaksi berupa respon positif dari komunikan. Sebagaimana batasan komunikasi yang mengharapkan pesan yang diberikan dengan sengaja disampaikan untuk mendapatkan respon, seperti pertanyaan yang diajukan memerlukan jawaban, instruksi yang diberikan juga perlu diikuti (Machfoedz, 2009).

Pada pertemuan pertama kali dengan klien, sebanyak $68,3 \%$ perawat gigi tidak menanyakan nama panggilan kesukaan dari kliennya serta $65,9 \%$ tidak memberitahukan identitasnya kepada klien. Stuart dan Sundeen mengatakan bahwa komunikasi terapeutik adalah suatu proses yang melibatkan usaha-usaha untuk menjalin hubungan terapeutik antara perawat dengan klien, dimana saling membagi pikiran, perasaan dan perilaku untuk membentuk keintiman yang terapeutik yang pada akhirnya akan mempercepat peoses penyembuhan klien (Priyanto, 2009). Proses perkenalan antara perawat dan klien sangat penting untuk kelancaran dan kehangatan hubungan antara perawat dan kliennya. Klien akan merasa dekat dengan perawatnya jika nama kesukaannya dipanggil, sehingga perawat dengan mudah menyampaikan informasi yang diperlukan selama perawatan gigi berlangsung.
Selain itu yang kondisinya yang belum baik adalah $41,5 \%$ perawat gigi belum mengakhiri perawatan gigi klien dengan cara yang baik yaitu mereka kurang dalam hal membuat rencana tindak lanjut bersama klien untuk perawatan giginya. Sehingga apa yang dilakukan perawat gigi dalam hal ini menunjukan bahwa mereka belum melakukan tahap terminasi secara optimal. Menurut Stuart dan Sundeen, tahap terminasi merupakan tahap perawat akan menghentikan interaksinya dengan klien, tahap ini bisa merupakan terminasi sementara maupun terminasi akhir. Terminasi sementara adalah terminasi yang dilakukan untuk berhenti berintegrasi dalam waktu yang sebentar, misalnya pergantian jaga atau sesi. Sedangkan terminasi akhir adalah terminasi yang dilakukan biasanya pada saat klien akan pulang kembali ke rumahnya setelah dilakukan perawatan. Pada tahap ini perawat mempunyai tugas : 1) mengevaluasi kegiatan kerja yang telah dilakukan baik secara kognitif, psikomotor maupun afektif; 2) merencanakan tindak lanjut dengan klien; 3) melakukan kontrak; 4) mengakhiri terminasi dengan cara baik (Sukendro, 2008).

\section{Sikap Perawat Gigi dengan Penerapan Komunikasi Terapeutik}

Hasil penelitian tentang sikap perawat gigi di puskesmas Kabupaten Agam tentang penerapan komunikasi terapeutik dapat dilihat pada tabel di bawah ini :

Tabel 2. Sikap perawat gigi di BP Gigi Puskesmas Kabupaten Agam

\begin{tabular}{cccc}
\hline \multirow{2}{*}{ No } & \multirow{2}{*}{ Sikap } & \multicolumn{2}{c}{ Total } \\
& & $\mathrm{f}$ & $\%$ \\
\hline 1 & Kurang & 22 & 53,7 \\
2 & Baik & 19 & 46,3 \\
\hline & Total & 41 & 100 \\
\hline
\end{tabular}

Dari Tabel 2 menggambarkan bahwa sebagian besar perawat gigi mempunyai sikap tentang penerapan komunikasi terapeutik yang kurang mendukung $53,7 \%$, dan yang mempunyai sikap yang baik sebanyak $46,3 \%$. 
Tabel 3. Sikap perawat gigi dalam menerapkan komunikasi terapeutik di BP Gigi Puskesmas Kabupaten Agam

\begin{tabular}{cccccccc}
\hline & & \multicolumn{4}{c}{ Penerapan komunikasi } & & \\
No & Sikap & \multicolumn{2}{c}{ terapeutik } & \multicolumn{2}{c}{ Total } \\
& & Kurang & \multicolumn{2}{c}{ Baik } & & \\
\cline { 2 - 8 } & & $\mathrm{f}$ & $\%$ & $\mathrm{f}$ & $\%$ & $\mathrm{f}$ & $\%$ \\
\hline 1 & Kurang & 18 & 81.8 & 4 & 18.2 & 22 & 100.0 \\
2 & Baik & 8 & 42.1 & 11 & 57.9 & 19 & 100.0 \\
\hline p.value $=0,008$ & & & & &
\end{tabular}

Tabel 3 memperlihatkan bahwa perawat gigi yang kurang menerapkan komunikasi terapeutik, lebih banyak pada perawat gigi yang mempunyai sikap kurang mendukung (81,8\%), dibandingkan dengan perawat gigi yang mempunyai sikap baik $(42,1 \%)$.

Hasil penelitian menunjukkan bahwa sebagian besar perawat gigi mempunyai sikap tentang penerapan komunikasi terapeutik masih kurang mendukung sebanyak 53,7\%, Sikap perawat gigi terhadap penerapan komunikasi terapeutik didapatkan hasil bahwa perawat gigi yang kurang menerapkan komunikasi terapeutik lebih banyak pada perawat gigi yang mempunyai sikap kurang (81,8\%), dibandingkan dengan perawat gigi yang mempunyai sikap baik $(42,1 \%)$. Hasil uji statistik didapatkan p.value $=0,008$, yang artinya ada hubungan yang signifikan antara sikap perawat gigi dengan penerapan komunikasi terapeutik. Hasil penelitian ini sesuai dengan penelitian terdahulu yang dilakukan oleh Herwin Hasan tahun 2002, yang menunjukkan terdapat hubungan yang bermakna antara sikap, dengan persepsi komunikasi terapeutik perawat.

Masih banyaknya sikap perawat gigi yang kurang mendukung dalam menerapkan komunikasi terapeutik ini kemungkinan disebabkan oleh beban tugas perawat gigi yang ada di puskesmas, disamping itu masih ditemui puskesmas dengan tenaga perawat giginya hanya 1 orang. Beban tugas ini mengakibatkan perawat gigi melaksanakan perawatan gigi pada pasien selekas mungkin, karena kegiatan yang selanjutnya sudah menunggu untuk dikerjakan seperti kegiatan posyandu, UKGMD dan UKGS. Umumnya perawat gigi sudah tahu tentang penerapan komunikasi terapetik, tetapi dalam pelaksanaanya perawat gigi tidak melakukan sesuai dengan yang seharusnya. Disamping bertugas di BP gigi, perawat gigi juga ditugaskan untuk turun ke lapangan. Perawat gigi melaksanakan tugas sesuai dengan standar kompetensi serta Tugas pokok dan fungsi perawat gigi di puskesmas, selain sebagai petugas pelayanan asuhan kesehatan gigi dan mulut di BP gigi juga sebagai petugas pelayanan asuhan kesehatan gigi sekolah dan pelayanan asuhan kesehatan gigi masyarakat (Depkes, 2007).

Dengan masih ditemukannya sikap yang kurang baik, maka reaksi yang diberikan atau diterima klien pun bisa menjadikan suatu pandangan yang negatif. Hal ini sesuai dengan batasan dari sikap itu sendiri yaitu : sikap adalah pandangan atau kecenderungan mental. Sikap (attitude) merupakan kecenderungan yang relatif menetap untuk bereaksi dengan cara baik atau buruk terhadap orang atau barang tertentu (Sukendro, 2008). Sikap menurut Azwar adalah suatu kecenderungan untuk merespon terhadap suatu obyek atau sekumpulan obyek dalam bentuk perasaan memihak (favorable) maupun tidak memihak (unfavorable) melalui suatu proses interaksi komponen-komponen sikap yaitu kognitif (pengetahuan), afektif (perasaan) dan konatif (kecenderungan bertindak) (Sukendro, 2008).

Hasil penelitian ini sesuai dengan pendapat Newcomb dalam Notoatmodjo, menyatakan bahwa sikap itu merupakan kesiapan atau kesediaan untuk bertindak. Terbentuknya penerapan komunikasi terapeutik yang baik, terlebih dahulu didasari sikap yang baik, dengan kata lain semakin baik sikap perawat gigi maka semakin baik juga praktik komunikasi perawat gigi (Sukendro, 2008).

\section{Pengetahuan Perawat Gigi dengan Penerapan Komunikasi Terapeutik}

Hasil penelitian pengetahuan perawat gigi tentang penerapan komunikasi 
terapeutik di Puskesmas Kabupaten Agam dapat dilihat pada tabel dibawah ini :

Tabel 4. Pengetahuan perawat gigi di BP Gigi Puskesmas Kabupaten Agam

\begin{tabular}{cccc}
\hline \multirow{2}{*}{ No } & Pengetahuan & \multicolumn{2}{c}{ Total } \\
& & f & $\%$ \\
\hline 1 & Kurang & 15 & 36,6 \\
2 & Baik & 26 & 63,4 \\
\hline & Total & 41 & 100 \\
\hline
\end{tabular}

Dari Tabel 4 memperlihatkan bahwa sebagian besar perawat gigi mempunyai pengetahuan yang baik tentang komunikasi terapeutik $63,4 \%, \quad$ sisanya $36,6 \%$ berpengetahuan kurang.

Tabel 5. Pengetahuan perawat gigi dalam menerapkan komunikasi terapeutik di BP Gigi Puskesmas Kabupaten Agam

\begin{tabular}{cccccccc}
\hline \multirow{2}{*}{ No Pengetahuan } & \multicolumn{4}{c}{$\begin{array}{l}\text { Penerapan komunikasi } \\
\text { terapeutik }\end{array}$} & \multirow{2}{*}{ Total } \\
\cline { 3 - 6 } & & \multicolumn{2}{c}{ Kurang } & \multicolumn{2}{c}{ Baik } & & \\
\cline { 2 - 6 } & $\mathrm{f}$ & $\%$ & $\mathrm{f}$ & $\%$ & $\mathrm{f}$ & $\%$ \\
\hline 1 & Kurang & 10 & 66.7 & 5 & 33.3 & 15 & 100.0 \\
\hline 2 & Baik & 16 & 61.5 & 10 & 38.5 & 26 & 100.0 \\
\hline p.value $=0,743$ & & & & & &
\end{tabular}

Tabel 5 memperlihatkan bahwa perawat gigi yang kurang menerapkan komunikasi terapeutik, lebih banyak pada perawat gigi yang berpengetahuan kurang $(66,7 \%)$, dibandingkan dengan perawat gigi yang berpengetahuan baik $(61,5 \%)$.

Berdasarkan hasil penelitian menunjukkan bahwa sebagian besar perawat gigi mempunyai pengetahuan yang baik tentang komunikasi terapeutik sebanyak $63,4 \%$, sisanya $36,6 \%$ berpengetahuan kurang. Berdasarkan hasil penelitian diketahui bahwa perawat gigi yang kurang menerapkan komunikasi terapeutik lebih banyak pada perawat gigi yang berpengetahuan kurang (66,7\%) dibandingkan dengan perawat gigi yang berpengetahuan baik (61,5\%). Hasil uji statistik didapatkan nilai p.value $=0,743$, artinya tidak ada hubungan yang signifikan antara pengetahuan perawat gigi dengan penerapan komunikasi terapeutik di BP gigi Puskesmas Kabupaten Agam.

Keadaan ini menunjukkan bahwa seseorang perawat gigi di Kabupaten Agam yang sudah berpengetahuan baik tidak selamanya menjamin bisa menerapkan komunikasi dengan baik pula, karena terbukti masih ditemukan sebagian besar dari yang berpengetahuan baik juga menghasilkan komunikasi terapeutik yang kurang. Seharusnya dengan adanya pengetahuan yang didapat bisa memberikan kemampuan untuk menilai baik dan buruk suatu keadaan, serta dengan adanya pengetahuan bisa lebih memberikan perubahan yang positif, tetapi dalam penelitian ini tidak terbukti.

Pengetahuan atau kognitif merupakan domain yang sangat penting untuk terbentuknya suatu tindakan seseorang (Isyrag, 2016). Pengetahuan yang diperoleh seseorang akan menimbulkan pengertian dan pemahaman terhadap pengetahuan tersebut. Dengan memahami sesuatu hal yang dipelajari, seseorang akan dapat mengadakan penilaian. Penilaian ini dapat positif atau negatif. Penilaian yang positif akan menimbulkan sikap positif, yang akhirnya akan berpengaruh pada perilaku positif terhadap sesuatu yang dipelajari tersebut (Sukendro, 2008). Pengetahuan merupakan pembentukan konsepsi perubahan, beragam pengalaman manusia, perubahan empirik manusia, perubahan kualitas persepsi, dan analisa pikiran atas objek pengetahuan (Isyrag, 2016).

\section{KESIMPULAN}

Dari hasil penelitian dan pembahasan yang telah diuraikan dapat disimpulkan bahwa penerapan komunikasi terapeutik sebagian besar responden dalam kategori kurang menjalankan (63,4\%), karena kebanyakan mereka tidak membungkukkan/ memiringkan badannya saat percakapan, tidak menanyakan nama panggilan kesukaan dari klien, tidak memberitahukan identitas 
dirinya kepada klien, tidak memberikan tanggapan terhadap perilaku klien serta tidak merencanakan tindak lanjut perawatan gigi klien. Variabel yang berhubungan dengan penerapan komunikasi terapeutik adalah variabel sikap, sedangkan pengetahuan merupakan variabel yang tidak berhubungan. Pengetahuan responden tentang penerapan komunikasi terapeutik sebagian besar kategori baik $(63,4 \%)$, namun pengetahuan yang masih kurang adalah tentang perlunya mengulang kata-kata klien dengan kata-kata sendiri, tentang tahap pra interaksi adalah tahap sebelum bertemu dengan klien, serta terminasi merupakan tahap berakhirnya interaksi. Sikap responden tentang penerapan komunikasi terapeutik sebagian besar kurang mendukung $(53,7 \%)$, diketahui sikap yang kurang mendukung antara lain tentang melakukan kegiatan perawatan gigi sesuai dengan yang telah direncanakan, tentang membuat rencana perawatan gigi tindak lanjut, serta melakukan tahap terminasi adalah suatu fase yang sulit.

\section{DAFTAR PUSTAKA}

Depkes RI., 2007, Keputusan Menteri Kesehatan Republik Indonesia nomor : 378/Menkes/SK/III/2007 tentang Standar Profesi Perawat Gigi. Jakarta.

Priyanto, A, 2009, Komunikasi dan Konseling: Aplikasi dalam sarana Pelayanan Kesehatan untuk Perawat dan Bidan, Salemba Medika, Jakarta.

Kristiana D., 2016, Pengaruh Komunikasi Terapeutik Terhadap Perilaku Kepatuhan Pasien Berobat Pulpitis di Poli Gigi Puskesmas Pucang Sewu Kota Surabaya : JIPTUNAIR

Kusmawan A.R., 2016, Infeksi Nosokomial di Klinik Gigi. http://wwwresearchgatenet/publicatio n/42349655 Infeksi Nosokomial Di Klinik_Gigi, Diakses tanggal 27 Desember 2016.
Isyrag, 2016, Subtansi dan Definisi Pengetahuan, Available from URL: http://Isyrag.wordpress.com.substansi -dan-definisi-pengetahuan/-177.pdf [cited 2016 Desember 27]

Machfoedz M., 2009, Komunikasi Keperawatan (komunikasi terapeutik). Yogyakarta: Ganbika

Sukendro, S.J, 2008, "Buku Ajar : Komunikasi Terapeutik Bagi Tenaga Kesehatan Gigi”, Forum Komunikasi Jurusan Keperawatan Gigi, Semarang. 